\title{
From Civil Islam towards NKRI Bersyariah? Understanding Rising Islamism in Post-Reformasi Indonesia
}

\author{
Associate Professor Leonard C Sebastian, PhD \\ Coordinator, Indonesia Programme \\ S. Rajaratnam School of International Studies (RSIS) \\ Nanyang Technological University - Singapore \\ E-mail: islcsebastian@ntu.edu.sg \\ Alexander R Arifianto, PhD \\ Research Fellow, Indonesia Programme \\ S. Rajaratnam School of International Studies (RSIS) \\ Nanyang Technological University - Singapore \\ E-mail: isalex@ntu.edu.sg
}

\begin{abstract}
The successful Defending Islam campaign against former Jakarta governor Basuki Tjahaja Purnama is clear evidence that Islamism is rising in post-Reformasi Indonesia, something that is not wellanalyzed in recent scholarships on Indonesian Islam. Influenced strongly by Civil Islam thesis, they have failed to study hardline Islamic movements due to its premises that: 1) the dominant mode of Islamic discourse in Indonesia is the moderate Islam represented by organizations such as Nahdlatul Ulama (NU) and Muhammadiyah, and 2) hardline Islamism represents a fringe element to the moderate theological discourses embedded in Indonesian Islam.
\end{abstract}

I argue that rising Islamism in Indonesia is attributed to the following factors: Hardline Islamist groups are able to promote their exclusivist public theologies using the following mechanisms: 1) Appealing for solidarity and common experiences as Indonesian Muslims to persuade more moderate Muslims to join their activities, 2) Using religious propagation (da'wa) institutions such as campus da'wa groups, state companies and bureaucratic institutions, and social media outlets to promote their theological viewpoints to Indonesian Muslims, and 3) Seeking out allies in national and local government in order to have their policy agenda (e.g., restrictions against religious minorities) implemented at both national and local levels. Meanwhile, moderate civil Islamic groups are losing their appeal because these groups (particularly NU and Muhammadiyah) have moved their central focus from religious propagation to social activism and politics.

Keywords: Indonesia, Islamism, civil Islam, social movement, religious intolerance, Reformasi

\section{INTRODUCTION}

On 2 December 2016, approximately 2 to 4 million protesters marched in Jakarta in the so-called Second Defending Islam rallies, demanding the removal of the city's governor Basuki Tjahaja Purnama (popularly known as Ahok) from office and for him to resign and be put on trial based on the charge that he had blasphemed Islam in one of his reelection campaign speeches. The rally was the largest mass mobilization protests held in Jakarta since Indonesia underwent its democratic transition after the 1998 Reformasi which toppled the country's long term dictator Suharto. The overwhelming force against Ahok shown in this and a number of other Defending Islam rallies was successful in turning public opinion of most Indonesians, and Jakarta voters in particular, against the governor, resulting in his re-election loss to Anies Baswedan, whom have touted his pious Islamic credentials, in the gubernatorial run-off election held on April 19, 2017. About three weeks later, he was convicted for committing blasphemy and was sentenced to twoyear imprisonment.

The organizer of this protest was an umbrella group called The National Movement to Guard the Indonesian Ulama Council's Ruling (GNPF MUI), in response to a religious ruling (fatwa) issued against Ahok in late October 2016 from the Indonesian Ulama Council, Indonesia's quasi-official arbiter of 
Islamic legal affairs. The group was organized by a number of hardline Islamist groups such as the Islamic Defenders Front (FPI), Hizbut Tahrir Indonesia (HTI), and Indonesian Islamic Community Forum (FUI), along with two dozen other Islamist groups. In addition to these hardline Islamist groups, tens of thousands clerics and activists from Indonesia's two largest Muslim organizations, Nahdlatul Ulama (NU) and Muhammadiyah, which are widely known as advocates of moderate Islam in the largest Muslim-majority country in the world, also participated in the rallies, despite the repeated calls from leaders of both organizations for them not to do so.

The success of Defending Islam rallies came about after a number of troubling signs regarding the rise of hardline Islamist groups in Indonesia over the past decade or so. In addition, dozens of intolerant actions committed by hardline groups like FPI against different religious minorities have taken place since the end of Reformasi in 1998, while both the security forces and the judiciary unable or unwilling to resolve them to the satisfaction of the groups who were victimized. Lastly, more Indonesian regions are adapting shari'a regulations over the past two decades. According to one recent study, at least 442 local shari'a regulations have been enacted by over 100 regional governments by 2016 (Pisani and Buehler 2017). These regulations require women to wear hijab in public, prohibit the consumption of alcohol and prostitution, and ban Muslim minority sects, such as Ahmadis and Shiites, within their respective localities. ${ }^{1}$

All of the above observations could serve as evidences that hardline Islamist groups have gained popular following among Indonesian Muslims and increasingly control religious opinion in Indonesia through their control of both conventional religious propagation activities (da'wa) (e.g., mosques, radio, and television networks) as well as online/social media da'wa activities (footnote here). Accordingly, Indonesian Muslims also increasingly showing their religiosity in public and, as indicated in opinion polls, are increasingly become politically conservative supporting actions ranging from public expressions of Islamic piety, the implementation of Islamic

\footnotetext{
${ }^{1}$ These figures do not include regulations in the form of local government decrees (Surat Keputusan) signed by regents, mayors, or governor as well as local agency's head (Kepala Dinas) decrees, which are increasing in frequency compared to local regulations (Perda) over the past few years.
}

(shari'a) law in whole or in part, increased intolerant actions against religious minorities, and so forth.

However, until the rallies took place, few scholars have written extensively about hardline groups such as FPI, FUI, and HTI, in favor of moderate Islamic groups like $\mathrm{NU}$ and Muhammadiyah. $^{2}$ I argue that the rise of hardline Islamist groups in Indonesia in the past two decades has gone relatively unnoticed because most scholars studying Indonesian Islam, in varying decrees, are informing their research based upon Bob Hefner's Civil Islam thesis, which argues that Islam in Indonesia is largely shaped by moderate Islamic groups that promote democracy, pluralism, tolerance and other liberal values that were internalized and made compatible with Islamic teachings by these groups. Hefner's emphasis on pluralist Islamic groups as drivers of Indonesian democracy, and his negative portrayals of hardline Islamist groups and activists who sought to bring about a more literalist interpretation of Islam in Indonesia, have inadvertently promoted more scholars to study the former group rather than the latter.

By treating hardline Islamism as an anathema to the Civil Islamist, Hefner has failed to take into account these groups seriously as civil society organizations which despite their theological differences, due share some, but not all characteristics as civil associations with their Civil Islamist counterparts, namely the fact that they are independent, voluntary associations where free discussion of ideas occurs and they promote their ideas freely to recruit new followers. However, they are advocating exclusive public theologies to promote their hardline Islamist agendas to the Muslim audiences as well as sympathetic policymakers, instead of inclusive public theologies promoted by civil Islamic groups. ${ }^{3}$ I argue the hardline groups are

\footnotetext{
${ }^{2}$ A number of scholars did focus their research on these hardline groups, including Wilson 2015 (on FPI), Ward 2009, Osman 2010, Muhtadi 2009, and Njoto-Feillard 2015 (on HTI), and Munabari 2017 (on FUI). However, the number of publications on these groups are still smaller compared to academic publications on moderate Islamic groups like NU and Muhammadiyah, as well as on Islamist parties like PKS.

${ }^{3}$ Exclusivist and inclusivist public theologies are concepts originally invented in Nukhet Sandal, Religious Leaders and Conflict Transformation: Northern Ireland and Beyond (New York: Cambridge University Press, 2017), p. 8 in her work which explores the role of religious groups in ending
} 
able to effectively promoted their exclusive public theologies in post-Reformasi Indonesia by taking advantage of the open public sphere created once democracy has taken hold in Indonesia, and by portraying their vision of Islam as simplistic, yet reassuring vision for millions of Indonesian Muslims who are feeling disenfranchised for the lack of socioeconomic mobility they are experiencing.

I propose hypotheses to explain why hardline Islamist groups managed to prevail over their moderate counterparts in post-Reformasi Indonesia, which are the following:

H1: Hardline Islamist groups managed to prevail over their moderate rivals due to the existence of a free marketplace of ideas, which increases the capacity of these groups to outbid their rivals in gaining new recruits among young Indonesian Muslims

As predicted by Hefner, Indonesia's democratic transition in 1998 have created a free marketplace of ideas where all civil society groups, irrespective of their ideological and political leanings, can compete and promotes their ideas and agendas within the Indonesian public sphere. However, two decades after this marketplace of ideas was created, hardline Islamist groups manage to outbid their moderate rivals by promoting their ideas as utopian visions with compelling future directions for Indonesian Muslims and by portraying moderate Muslims as 'deviant' agents of the status quo who represent Indonesia's past. The Islamist's manpower and financial resources enabled them to strategically market their utopian vision to potential recruits (university students, junior bureaucrats and security officials), which in the end decided to join their movements instead of the moderate Islamic groups. In the end, they manage to outbid their rivals in the marketplace of ideas. Outbidding is operationalised as the increasing number of new members for new Indonesian hardline groups such as the Islamic Defenders Front (FPI), Hizb-ut Tahrir Indonesia (HTI), and Prosperous Justice Party (PKS) over mainstream, moderate Islamic groups such as Nadhlatul Ulama (NU) and Muhammadiyah, including, but not limited to the membership of

violent conflicts and promote peace in Northern Ireland. I extend the concepts further in this work by exploring the mechanisms by which religious (Islamic) groups promote their public theology and win over potential converts and followers in the Indonesian context. young Muslims in high school or university propagation $(d a ' w a)$ institutions.

H2: Politicians and state officials develop alliances and networks with hardline Islamist groups in order to retain their political power. The end result of these alliances is the lack of effective institutions that can protect moderate Muslims and religious minorities from the predatory actions of hardline Islamists.

Hardline Islamist's success to dominate the marketplace of ideas in turn made them politically significant in the eyes of Indonesia's political elites. Opportunistic politicians and security apparatus are feeling threatened by the hardline groups and their ideologies. However, since repressing them is no longer an option in a democratic Indonesia, they decided to develop alliances with these groups and gain these groups' support in order to retain their political power, achieved largely by winning reelections to the elected officers they hold. In return, hardline Islamist groups had proven themselves as reliable get-out-the-vote partners for these politicians who need to be re-elected as office holders in order to secure their political survival. As a result of these alliances, state actors and hardline Islamist groups tend to support one another, creating the lack of institutions that can effectively protect moderate Muslims and religious minorities from the predatory actions of hardline Islamists. Hence, we saw increasing intolerant actions and outright persecutions of numerous religious minorities, whether they are Muslim minorities and non-Muslims two decades after the Reformasi took place.

This paper is divided into the following sections. First, it summarizes the Civil Islam thesis in understanding contemporary development of Islam in Indonesia. Then, it highlights its shortcomings and lack of ability of thesis proponents to properly account for signs of rising Islamism within the country, by reviewing the preconditions of the theses and explaining why or why not these preconditions have been successfully met in post-Reformasi Indonesia. Then it seeks to explain why hardline Islamist managed to dominate the theological and political discourse within the country after its democratic transition in 1998 and the mechanisms they used to grow their followers and increase their influence in post-Reformasi Indonesia, and explains why the moderate, civil Islamic groups are not able to match them. Lastly, the paper will provide assessments and offers a number of recommendations on the way forward for the future of Indonesian politics and society in an age of rising Islamism. 
Before proceeding, however, we want to be clear that in the critical analysis of Hefner's thesis below, we do not subscribe to the view that Islamic and nonIslamic world are destined to engage in a conflict over their theological and political differences, based on irreconcilable ideological and civilizational differences between the two societies. We also do not share the view that hardline Islamism represents a new religious totalitarianism that imposes inherent danger not just to other Muslims, but especially to the Western civilization and society. The problem within Islam (or any other religious traditions) is not its theological frameworks, but instead is the politicized and formalist interpretation of these frameworks to benefit a small group of clerical and political elite. We argue Islam is a religion with multiple theological interpretations and diverse traditions and practices, some are inclusivist/pluralist, while others have a more exclusivist viewpoint, subscribe to a more legalist interpretation of Islam and rejects any deviations from basic Islamic tenets prescribed in the Qur'an and the Hadith, including those that have their origins from local cultural practices and traditions.

We do argue in my analysis below that the latter interpretation of Islam has gained significantly within contemporary Indonesian society over the past three decades, due to the influence of hardline Islamists movements and activists over their moderate counterparts discussed earlier. This growing conservatism can be seen both within the two main branches of Islam in Indonesia - the more orthodox modernists and the more cultural-sensitive traditionalists. It threatens the civil pluralist fabrics of Indonesian Islam and the future of Indonesia as a moderate and democratic Muslim-majority nation.

\section{Overview of Civil Islam Thesis}

Over the past two decades, the most enduring paradigm in the study of Indonesian Islam is the Civil Islam thesis. First articulated by anthropologist Robert Hefner, it is an extension of earlier paradigms developed to understand Islam in Indonesia, which is assumed to have be characterized by moderate, pluralist, even syncretic characteristics compared to Islamic practices in other parts of the world. It is a view shared among the early generation of Islamic scholars, including Clifford Geertz during the early 1950s that became the cornerstone for his landmark study the Religion of Java (1960). Hefner's Civil Islam is a more sophisticated framework he developed to portray more accurately the image of Indonesian Islam promoted in the works of Geertz, which argued that the majority of Javanese Muslims during the 1950s were syncretic (abangan) Muslims. It is based upon Hefner's observations obtained during his fieldwork during the 1970s and 1980s, a time where Java underwent rapid state-led Islamization and abangan's culture and practices were on a steady and permanent decline.

Building upon Robert Putnam's framework on the role of civil society in promoting sustainable democracies, the book was written as a response to Samuel Huntington's provocative "Clash of Civilizations" (1996) thesis which states that Islam and democracy is incompatible due to the differing values between Western and Islamic civilizations, as democracy in the former was able to flourished due to the strict separation between religion and the state, something that is supposed to be missing in Muslim societies. Hefner replies that the real preconditions for democracy is not necessarily a strict separation between religion and the state, Instead, he made a Putnamesque argument that the existence of strong civil society associations and organizations, many of which are built on religious foundations, are the main preconditions of strong democracy. Furthermore, he argues that the normative values that built democracy - liberalism, pluralism, and tolerance - are universal and are desired by their supporters, including Muslims, worldwide.

Hefner stipulates that there are three preconditions of democracy to be successfully taken roots within a society. The first condition is the existence of "civil organizations characterized by voluntarism, independent associations, and a balance of power between state and society as well as among civil society organizations themselves;" (Hefner $2000: 215)$. The second condition is the existence of "a public culture that draws on these separate experiences to promote universal habits of participation and tolerance” (Hefner 2000: 215). Hefner's public culture reflects his views that a good democracy must be based on tolerance and pluralism, as he defines it as:

a noncoercive culture that encourages citizens to respect the rights of others as well as to cherish their own...[It] depends on mediating institutions in which citizens develop habits of free speech, participation, and toleration (Hefner 2000: 13).

He further elaborates that this "mediating institutions" are voluntary civil society organizations, which includes Muslim civil society organizations.

The third and final condition of a strong democracy according to Hefner is the existence of "a 
civilized and self-limiting state” (Hefner 2000: 215). Hefner further elaborates that:

...civil society is not opposed to the state but deeply dependent on its civilization. The state must open itself to public participation. At the same time, independent courts and watchdog agencies must be ready to intervene, when....some citizens or official tries to replace democratic proceduralism with netherworld violence.

In short, in addition to the existence of strong civil society organizations and democratic public culture, successful democracies need a limited government that is open for public participation (including from civil society organizations), and are protected by the self-serving ambitions of its officials through the workings of check-and-balance institutions such as the court and watchdog government agencies.

Elaborating on the Indonesian case for the rest of his book, Hefner argues that Indonesian has a long history of independent civil associations that were largely initiated by different Islamic groups thousands of traditionalist pesantrens that became the cornerstone of the Nahdlatul Ulama (NU) (founded in 1926), and reformist scholars and middle class traders who founded Muhammadiyah (founded in 1912) along with other Islamic reformist organizations in the early $20^{\text {th }}$ century. All of these Muslim associations were founded outside of the Dutch colonial government control, helping to legitimize themselves alongside Indonesian Muslims and propelled them to be the cornerstone of Civil Islam in Indonesia as key actors in Indonesia's struggle for independence as well as its postindependent politics.

Indonesian Civil Islam was re-invigorated during the 1970s and 1980s with the arrival of neomodernist thinkers such as Harun Nasution (19191998), Nurcholish Madjid (1939-2005) and Abdurrahman Wahid (1940-2009). These thinkers are widely considered as neo-modernist thinkers, who "mixes passages from the Qur'an with discussions on current affairs, modern moral dilemmas, and sometimes, Western political theory" (Hefner 2000: 10). They managed to combine classical Islamic theology and Western social theory to produce commentaries of Indonesian society during the New Order period. These commentaries are designed to reform Indonesian Islam, moving it away from the Islamic state ideas offered by their conservative predecessors, and updating Islamic thought to show its compatibility with modern ideas such as democracy, pluralism, and tolerance. As the New Order era came to an end in the 1990s, the neo- modernist intellectuals played a pivotal role in encouraging the peaceful resignation of Suharto from his 32-year rule in 1998 and transforming Indonesia into a democracy the following year.

In contrast to these neo-modernist intellectuals, Hefner portrayed conservative Islamist activists who sought to turn Indonesia to become an Islamic state in a negative light. He criticizes these conservatives as those who "invoke the idea of Islam as 'religion and state' to justify harshly coercive policies" Hefner elaborates that the notion of an Islamic state does not exist in the Qur'an and worse, its promotion by proponents would have promoted an authoritarian rule who justify religion as the basis of rule:

By concentrating power in rulers hand, statist Islam only increases the likelihood that Islam's high ideals will be subordinated to vulgar political intrigues. Time and time again we see unscrupulous despots wrap themselves in the mantle of Muslim piety. Not coincidentally, the Islam they promote is typically a neofundamentalism hostile to pluralism, justice, and civil decency.

In the Indonesian case, Hefner portrays Islamist activists during the late New Order period, such as Adi Sasono, Din Syamsuddin and Ahmad Sumargono as the primary opponents of the progressive Civil Islamic thinkers. Referred by Hefner as supporters of 'regimist Islam,' they were collaborating with elements of the Suharto regime during the final years of his rule to develop the so-called regimist Islam, those who want Islam to be imposed upon society under the iron grip of an authoritarian (Suharto) rule. These activists assisted Suharto's attempted crackdown of the Civil Islamist by staging a campaign of violence against moderate Islamic activists and religious minorities and destabilizing the country by sponsoring Islamic militias during the turbulent years of Reformasi between 1997 and 1999.

In his conclusion, Hefner was confident that against all odds, Muslims will choose to have a state based on democratic, Civil Islamic principles rather than a Islamic state based on the shari'a law. He believes the latter option will be rejected by the majority of Muslims, because:

....it is out of step with the pluralism and movement of our age....For Muslims believers then, the real danger in the union of Islam and state is that it ends by subordinating Islam to state. Faced with this peril, other Muslims will look to democratic ideals, and some variant of civil Islam, to guard their faith and maintain an ethical compass amid the roaring flux. 
Hefner concluded "Civil Islam" by arguing that in the end, every societies, Muslim or otherwise, will adopt civility, democracy, and pluralism he believes there are "the relevant ideas for our age". He further elaborates that:

Our democratic confidence should be based on the conviction that the message of freedom, equality, and plurality, is not narrowly circumscribed....Democratic ideals are broadly appealing because they respond to circumstances and needs common across modern cultures.

\section{Analysis of Civil Islam thesis}

As Civil Islam ended as the Suharto regime fell and Indonesia entered a new democratic era, Hefner's book gained a wide following among scholars of Indonesian Islam (both Indonesian and Western-based) who sought to explain Indonesia's successful democratic transition and the role of Islamic civil associations and activists in Indonesia's transition to democracy. While most of the scholarships based upon the Civil Islamic paradigm do not strictly follow the theoretical frameworks put up by Hefner, they share its optimism that moderate, if not liberal interpretations of Islam have prevailed in Indonesia and that it will continue to shape Islamic theological and socio-political discourse in postReformasi Indonesia. Among proponents of the thesis are Indonesian scholars influenced by Hefner's work who obtained faculty positions in the State Islamic University (UIN) campuses in Jakarta, Yogyakarta and others. They shared his positive outlooks regarding the future of Islam in Indonesia. Scholarships within this period tend to focus on the impacts of moderate Islamic groups like NU and Muhammadiyah in shaping the post-Reformasi Indonesian society or on their affiliate organizations.

Much of the scholarships on conservative Islamist groups tend to focus on political parties like the Properous Justice Party (PKS) and the United Development Party (PPP). Utilizing the inclusionmoderation thesis commonly employed to analyze the electoral behavior of religious parties, they tend to highlight the ability of these parties to moderate their political goals and strategies and work together with secularist and non-Muslim parties and groups in order to win additional supports in the ballot boxes. ${ }^{4}$

\footnotetext{
${ }^{4}$ Scholarships on Indonesian Islamist political parties and their electoral moderation strategy include Platzdasch 2009, Hamayotsu 2011a, 2011b \& 2011c; Buehler 2012, Tomsa 2012, and Tanuwidjaja 2012.
}

However, we must make a distinction between Islamist parties which have the incentives to moderate themselves (at least in their political platforms and campaign rhetorics) and hardline civil society groups, who has less incentives to moderate their ideologies and strategies because they do not compete in national and regional elections. It is arguably the latter that have made significant gains in terms of membership and influence in post-Reformasi Indonesia over the next decade or so.

Consequently, the above scholarships tend to produce an overly positive outlook toward the future of Islam in Indonesia and overlook the fact that in post-Reformasi Indonesia, hardline Islamist groups have made significant gains in their theological and political outreach. They are slowly overshadowing their moderate Islamic counterparts in the struggle over which factions represent the "true" interpretation of Islam among Indonesian Muslims. Because hardline Islamist groups like FPI, FUI, and HTI are not considered as civil associations which shares liberal and pluralist public culture like organizations which embrace civil Islamist characteristics, they are often dismissed in this literature as fringe groups with hardline Islamist agenda that do not represent the ideas of most Indonesian Muslims, which remains moderate, pluralist, and tolerant in their outlook.

In the process, proponents of Civil Islam thesis have ignored signs of rising Islamism in Indonesia. These include the rapidly growing number of local Islamic regulations adopted by regional governments across Indonesia. They also ignored the facts that hardline Islamist groups such as FPI and FUI often played a role in promoting the enactment of these Islamic regulations, working together with regional politicians and conservative activists within local NU and Muhammadiyah branches who are sympathetic with their goals. As the Islamist groups are gaining popularity in Indonesia, the growth of progressive Islamic groups such as the Liberal Islam Network (JIL) and the moderate activists within NU and Muhammadiyah are losing their influence within their respective organizations, indicated from their inclusion from the leadership board of both organizations at their respective 2005 national congress. Even though moderate NU activists managed to retake control of the organization in 2010 and elected Said Aqil Siradj, a relatively moderate cleric, to become the organization's general chairman, the conservative faction within the $\mathrm{NU}$ is still significant player within the organization, and often manages to overshadows activities and initiatives 
Finally, proponents of Civil Islam thesis failed to anticipate the growing number of intolerance incidents against different religious minorities, that have steadily increased throughout Indonesia within the past decade or so. Usually explained away as acts by fringe groups that have aligned themselves with self-interested local elites, the acts of violence against religious minorities has grown steadily over the past two decades, raising questions on why the number of incidents continued to grow steadily while Indonesia is supposed to be a consolidated democracy. Given high number of religious intolerance incidents, we can conclude that these acts are not conducted by a small minority of radical Muslim activists (now approximately numbering 200 incidents per year, according to the Setara Institute), but instead are reflections of growing Islamization of the Indonesian society that have steadily becomes more willing to express intolerance toward religious minorities. To answer why hardline groups managed to overtake moderate Islamic groups in post-Reformasi Indonesia, an examination on whether the three preconditions of successful democratic transition Hefner had outlined in his book have been met. As will be outlined shortly, only the first of these preconditions were met, while the other two have not been satisfactorily established in post-Reformasi Indonesia. These are something we seek to explain in the following section.

The presence of independent, voluntary civil associations

Of the three preconditions of sustainable democracy outlines by Hefner, this is the only preconditions that has largely been met in Indonesia's two decades journey as a democracy. Indonesia currently has tens of thousands of organizations, many of them are based on Islamic principles of different ideological and political outlook. The activisms of these groups have become more vibrant as Indonesia embarked on its democratic transition. Some scholars have argued that it was only because of such activisms and the role these groups played as unofficial watchdog to the Indonesian states that Indonesia's democracy can be consolidated today.

However, while pluralist civil Islamic groups are thriving in the post-Reformasi period, they are not the only one existing. Hardline Islamist groups which have long operated underground during the Suharto period ae now able to compete in the marketplace of ideas created when Indonesia made its democratic transition in 1998. Groups like the Tarbiyah Movement and Hizbut Tahrir Indonesia (HTI) decided to incorporate themselves as legal entities. The Tarbiyah established the Prosperous
Justice Party (PKS) in 1998, while HTI managed to obtain legal recognition in 2000. Other hardline Islamist were also formed, for instance the Islamic Defenders Front (FPI), established in 1998 with the blessing of a number of senior high-ranking Indonesian security officials and, the Islamic Community Forum (FUI), which was established by disgruntled former HTI activists in 2008. Unlike Hefner's assertions, most of these new Islamic groups do not have pluralist outlook as envisioned in his civil Islam conceptualization. Instead, all these groups subscribed to the literalist reading of Islam which calls for the Islamization the state, "to establish Islamic symbols and authority structures in the state which ensure their observance". However, each groups disagree from one another on the ideal regime type this new state should be, with HTI advocating for Indonesia to be part of a global caliphate system, while groups like FPI and FUI called for the establishment of Islamic law within the entity of a single unitary Indonesian state (NKRI Bersyariah).

While hardline groups like PKS, HTI, and FUI reject liberal and pluralist principles, they do share some characteristics that are present in other civil associations with more pluralist outlook, namely that they are voluntary, independent associations where members can freely discuss their ideas. These groups can express and share their ideas to other Muslims whom they seek to recruit. Most importantly, however, many hardline groups (especially PKS and PBB) have affirmed their commitments toward democracy and the rule of law as part of their legacy as descendants of the Masyumi, Indonesia's first Islamic party which thrived for advocating for both shari'a implementation and democratic rule during the 1950s. Hence, Hefner was incorrect in branding all hardline Islamist groups to be undemocratic, just because they adhere to the strict Islamist ideology and formally reject principles of liberalism, pluralism, and tolerance as their organizations' platforms.

Hefner also assumes that pluralist Muslims share a similar notion of pluralism and tolerance as individualistic values similar to the understanding shared by their Western counterparts. In his new book, Jeremy Menchik shows that while Indonesian Muslims do have tolerant and pluralist attitudes toward religious minorities, their tolerance toward these groups is not based on individual, but rather communal-based tolerance. Many Muslims, whether they subscribe inclusivist or exclusivist political theology, based their conception of tolerance from 
classical fiqh texts, which recognizes religious group such as Christians and Jews as communal groups protected under the terms of an Islamic social contract. Unlike individual tolerance widely practiced in the West, communal tolerance emphasizes group rights rather than individual rights, and it puts an emphasis on "the primacy of religious beliefs over other values and in sharply differentiating between minority rights in social and religious affair". Therefore, "it does not recognized unlimited individual freedom of conscience" which means that religious groups can sanction and forbid any "deviant' sects within their traditions. Under communal rights regime, Muslims can develop tolerant attitudes toward Christians, Buddhists, and other faith traditions, while at the same time treats Muslim minorities such as Ahmadis and Shiites as heretics that should be suppressed.

Because even the moderate inclusivist Islamic groups in Indonesia subscribe to the notion of communal tolerance stated above, this is something that more exclusivist groups exposed in their campaign against Ahmadis and Shiites. By declaring both groups as heretical sects that should be prohibited by the state, hardline groups managed to develop common grounds with numerous members of more mainstream religious groups and managed to develop alliances with them, which explains why attacks against these Muslim minorities often get support not just from the hardline groups, but also from many NU and Muhammadiyah members as well. This is something not anticipated by Hefner in his work, as he assumes the civil Islamists from both organizations view minority rights from the perspective of individuals, not groups. Hence, his thesis cannot anticipate why many followers of moderate Indonesian Islamic groups can join forces with their more hardline counterparts to condemn and attack these Muslim minorities and why despite their different theological affinities, they can bound together to commit uncivil acts against these minorities.

Having a common notion of communal tolerance is not the only common ground where Islamic civil associations with exclusivist and inclusivist theology share a similar frame of references. Recent scholarships in Indonesian history have shown that in pivotal moments of Indonesian history, Islamic activists from diverging ideological persuasions managed to set aside their differences and united together over a common cause when they felt Islamic principles needs to be promoted and/or defended from a major threat. Just before the country's independence in 1945, inclusivist and exclusivist Muslim leaders were able to unite to support the Jakarta Charter, which called for the implementation of shari'a law for Muslim citizens of the newly independent state. They managed to do so in other pivotal moments of Indonesian history, during the 1959 Constituent Assembly debate on whether Indonesia should adopt Pancasila or shari'a principles as its national ideology as well as during the anti-Communist crackdown of 1965/1966.

Seeing from this perspective, the Defending Islam rallies is another occasion where Muslims from differing ideological persuasions is united to defend Islam that they perceived is under threat from Ahok's allegedly blasphemous act against the Qur'an. Millions of Muslims, including many from the normally moderate, inclusivist groups like NU and Muhammadiyah felt the need to join the protests, to ensure that this act does not go unpunished. The hardline groups' ability to portray the incident as a unifying call for all Indonesian Muslims to act was successful to bring activists and groups that are normally divided ideologically and politically to join the rallies together.

However, despite the existence of these occasions in Indonesian history where Indonesian Muslims from differing ideological persuasion can band together Hefner treats pluralist and hardline Islamic groups as two binary opposite groups that could not come together if situation or circumstances suit their interests. And he seems to consider only the former group as a group with the credentials to become proper civil society groups, ignoring the facts that most hardline groups can also be categorized as such due to their having voluntary membership associations and are free to spread their ideas to others (including pluralist and inclusivist Muslims) in post-Reformasi Indonesia.

\section{The presence of a pluralist public culture}

Twenty years after Reformasi, a pluralist public culture has not taken a hold in Indonesia's public sphere. in the everyday discourses of its civil society organizations. As a matter of fact, the public culture of Indonesian civil society is getting worse over the past two decades, with the increase appeal of hardline Islamist groups, the of their da'wa activities at public universities, high schools, and social media, while the appeal of moderate, civil pluralist Islamic groups seem to be lukewarm, if not declining. The opening of public space in post-Reformasi Indonesia to all types of Islamic ideas, both inclusivist and exclusivist ones, have resulted in large gains for the exclusivist hardline groups, while the moderate pluralist group seems to be declining in both 
membership as well as influence in the Indonesian politics and society. Consequently, one can argue that the Indonesian public culture is increasingly becoming more exclusivist instead of pluralist in recent years.

In the past hardline Islamic groups which promotes exclusivist public theology have fewer venues to express their ideas to the general public during Suharto's New Order, as the regime threatens any groups that expressed more illiberal and exclusivist ideas with potential arrests and other forms of reprisals (the so called ethnicity, religion, race, and groups (SARA) injunction). That is why many hardline activists who started out in the Tarbiyah and Hizbut Tahrir movement during the New Order era had to start their career as Islamist activists underground, limiting the appeal of these groups to certain niche within the Indonesian society such as university campuses.

The opening of public space during the Reformasi period has managed to help these groups to be able to promote their ideas freely to prospective members, utilizing any locations, target groups and strategies/tactics they have in their disposal. As elaborated later in the next session, within the past two decades hardline groups such as PKS, HTI, and others have been very successful in recruiting new followers both using conventional da'wa approach (e.g, recruiting new members within high schools and universities) as well as via new outlets such as television, social media, and the internet. In the process, they managed to promote their exclusivist public theology to more new members while putting Islamic groups with inclusivist public theology on the defensive both in terms of their membership as well as influence within the Indonesian society.

Islamist da'wa organisations sponsored by the Tarbiyah Movement (predecessor to PKS) as well as by HTI rapidly grew during the 1980s and 1990s, while their small, secretive nature helped them to escape constant surveillance from Suharto's security apparatuses. They gained popularity because young Muslims from relatively secular or non-pious Islamic background began to seek deeper understanding of Islam by attending da'wa events sponsored by these organisations. Through a propagation method called usroh - small, cell-like communities of prospective activists (cadres) of between 4 to 6 members, campus da'wa groups promoted strictly literalist interpretation of Islam to prospective cadres. By the end of their usroh training, cadres of these campus da'wa organisations become highly pious and dedicated activists who are willing to dedicate their lives to support their respective organisations, within their campuses and beyond.

By 1990s, campus da'wa organisations have dominated public discourses at most state universities, as their activists were frequently elected unto student government positions at elite state universities such as ITB, IPB, University of Indonesia (UI) in Jakarta, Gadjah Mada University (UGM) in Yogyakarta, and Airlangga University in Surabaya. They flourished even further in postSuharto Indonesia, as they are now able to propagate their da'wa activities under a democratic political environment without facing any legal restrictions and they are free to pursue political activism both within the campus and beyond.

At the same time, campus da'wa organisations sponsored by moderate Muslim organisations such as PMII (Nahdlatul Ulama), IMM (Muhammadiyah), and the Islamic University Students Association (HMI) began to move their primary focus away from Islamic propagation to train their members to be activists for political parties their respective organisations have sponsored - the National Awakening Party (PKB) for NU, the National Mandate Party (PAN) for Muhammadiyah, and the secular nationalist Golkar Party for HMI activists. This leaves an open space within the campus public sphere that are being filled by Islamist campus $d a$ 'wa organisations. Already prominent due to their superior organisational skills, they continue to increase their influence at university campuses during the 2000s and 2010s as during this time, moderate campus organisations have largely left public discourses on Islam to the hardline campus da'wa groups.

Accordingly, these groups proceeded to use universities as one of their vehicles to proceed with their agenda to change the mindset of young Indonesian Muslims toward a more exclusivist Islamic political they are also using university students they have recruited to spread these teachings among junior and senior high school students who are about to bcome their pupils once these students have received their teaching credentials. Hardline groups like HTI especially thrives in state teachers training universities (formerly the IKIP institutes), where they targeted newly minted students about to become public high school teachers to become their cadres. Many of these teachers presumably managed to pass on their exclusivist ideas among their pupils, resulting in recent opinion polls which showed that more than half of public high school students in West Java are endorsing the idea of an Islamic caliphate regularly promoted by HTI. 
Campus da'wa is just one means by which the hardliners managed to spread their exclusivist ideas to potential followers. Hardline groups are also active in sponsoring new forms of da'wa, ranging from Friday da'wa activities in large state institutions, companies, and shopping malls. The internet and social media sites have become new outlet for hardline groups to propagate their messages over the past decade or so as large number of Indonesians have become users of social media outlet such as Facebook, Twitter, and others, something that is effectively used by Islamist groups to propagate their views. Over the past decade, these outlets are increasingly being used by hardline groups to promote their exclusivist agenda. In addition, the hardliners also controlled social media da'wa, with popular sites such as Arramah.com, Suara Islam Online, Hidayatullah.com, VOAIslam.com, and others are gaining popularity among internet users looking for religious content online, as these sites offered literalist, orthodox interpretation of Islam that are being articulated in clear and simple manner, something that meets the characteristic of social media world that is rapidly changing how young Muslims learn about Islamic principles. Hardline preachers and groups have mastered over the past decade, beating their moderate pluralist rivals, which often does not have clear and simple theological answers to provide, that can effectively counter the theological interpretation of the Islamists.

In addition, hardline preachers tend to dominate television and online (social media) da'wa activities. This can be seen from the popularity of TV da'wa programs hosted by conservative preachers such as Abdullah Gymastiar (AA Gym), Bachtiar Nasir, and Yusuf Mansyur, which generated high ratings and is watched by millions of Muslims throughout Indonesia. ${ }^{5}$ These preachers were instrumental in the Anti-Ahok movement, probably helping to bring tens of thousands of their followers as well. As these TV and social media preachers gained popularity, many traditionalist ulama who in the past became the center for Islamic knowledge within their respective localities are declining in their popularity, especially among young people who would rather listening to an online da'wa via Youtube or other social media outlets.

\footnotetext{
${ }^{5}$ A growing number of scholarships have focused on the role of these conservative TV preachers and their growing influence among the Indonesian Muslim community. These include Hoesterey (2016) and Kailani (2015).
}

The traditionalist ulama who managed to have gained broad following for their da'wa activities tend to be young, Middle Eastern-educated ulama, with more conservative theological leaning, for instance Idrus Ramli and Buya Yahya. Both are founders of NU Garis Lurus ("True Path NU”)- a faction within the NU who seeks to roll back progressive and pluralist theology instituted by the late Abdurrahman Wahid within the NU, for they believe these ideas "they have corrupted the organisation's original aim as an Islamic organization adhering to Sunni principles (Ahlus Sunnah wal Jamaah)". Even though they formally reject any linkages with Middle Eastern Islam influenced by Wahhabi and Salafi theology, their agenda is very identical to the agenda proposed by other Indonesian hardline Islamist groups. The fact that preachers affiliated with the Garis Lurus faction are among the most popular traditionalist preachers, particularly among young NU followers, spells doom for the future prospect of $\mathrm{NU}$ as a moderate, pluralist Islamic organization as preachers such as Ramli and Yahya are likely to be the future leaders of the largest Muslim organization in Indonesia (and the world) fifteen to twenty years from now. The same phenomena can be said within the Muhammadiyah as well. Young Muhammadiyah leaders such Dahnil Ansar Simandjuntak, chairman of the Muhammadiyah University Students Association (IMM), have had links with conservative Islamist groups from the time they were attending universities. This is why IMM was one key FPI allies and it managed to supply hundreds of thousands of supporters, primarily IMM's own cadres, as participants of the Defending Islam rallies.

One clear evidence that hardline groups have successfully changes Indonesia's public culture to reflect their hardline, Islamist, theological position is in the recent treatment members of religious minorities, especially Muslim minority sects such as Ahmadis and Shiites. While there have been movements directed against these minority groups, for instance, in the MUI fatwa against the Ahmadis (Burhani 2014) and critical commentaries made by a number of MUI and other senior clerics against Shiism in the 1980s and 1990s, the discourses against religious minorities became even less conducive against them after the post-Reformasi period, as hardline groups have more opportunities to express their viewpoints freely with few voices, whether from the state or from civil society, willing to openly protect these minorities from attacks from the hardline Islamists. A number of hardline groups such as FPI, FUI, and HTI even band together to successfully lobby former President Yudhoyono to issue the joint ministerial regulations on the Ahmadis 
that severely restricted the group's religious freedom in 2008.

Headlines regarding attacks on Ahmadis, Shiites, and other religious minorities, are also being supported by more systematic analysis. Data from the Setara Institute, an NGO that monitors attacks against Indonesian religious minorities, has shown that incidents of religious intolerance in Indonesia have increased by 50 percent, from 177 in 2014 to 270 in 2016. Needless to say, the frequent attacks directed against these minorities were the results of growing intolerance against both Ahmadis and Shiites that were generated by government regulations which limit their religious freedom. These shows that as hardline Islamic groups with more exclusive public theology gained more followers and popular support, the public culture of civil associations in Indonesia also become less tolerant against religious minorities and are becoming even less pluralist and tolerant, away from Hefner's visions for an open and pluralist public culture articulated in his book.

\section{The presence of a self-limiting state}

Among the preconditions for a sustainable democracy offered by Hefner in his book, this was not found in Indonesia under Suharto's thirty years authoritarian rule and it remains elusive in postReformasi Indonesia today. The Indonesian state remains weak and its apparatus are vulnerable to corruption as well as undue influence of powerful actors, whether they are powerful businessmen who sought favors from the government or hardline groups who sought to pressure government officials and politicians to fulfill their demands to impose national and local regulations to strengthen public Islamic expressions or to discriminate against religious minorities. Reformed or newly established institutions designed to counterbalance the power of the state often languished, because they are being weakened by powerful politicians or groups who sought to benefit from the state's favors, or they are being underfunded and neglected by the state so that they are not able to satisfactorily perform their mandated functions.

The Indonesian Parliament (DPR) who earlier gained considerable new powers to keep the President in check - and later signal that it was willing to use its power to remove the President by impeaching former president Abdurrahman Wahid in 2001, is now perceived as one of the most corrupt political institutions in Indonesia, thanks to the dozens of scandals involving current and former Parliament leaders as well as many of its members. Political parties which sat on the DPR tend to be personalistic parties led by senior politicians or wealthy businessmen who sought state power and patronage once their parties have entered a coalition arrangement with the ruling regime. The parties run the DPR like a cartel so that there is no real competition between the parties and party member/MPs just sit down and collect patronage/spoils by the virtue of their positions. Party leaders also exercise tight control over parliamentary positions and allocation of funds, to discourage dissent from rank-and-file legislators, centralizing power at the hand of a collective oligarchy.

New state institutions established in the early Reformasi period, such as the Constitutional Court (MK) and the Corruption Eradication Commission (KPK) were instituted with mandates to put a check on dubious laws and predatory actions conducted by members of the executive and legislative branches. However, after some initial success, both institutions ability to clamp down on legally dubious laws and corrupt activities of government officials and parliamentarians are now being called into question. A number of MK justices (including a former chief justice) have been arrested for corruption allegations, while senior KPK leadership have been forcibly removed from office after being falsely accused of wrongdoings by their critiques within the government and the DPR.Hence, the prospect of both institutions to effectively counter-balance potential abuses by ambitious politicians in both executive and legislative branches remain in doubt.

Given the failure of these institutions to function properly to limit the power of the state to be exploited by self-interested office holders, power in post-Reformasi Indonesia rests at the hand of a small number of senior politicians and well-connected businessmen with close connections to them who are commonly known as the oligarchs. ${ }^{6}$ While the

\footnotetext{
${ }^{6}$ A number of scholars have grounded their research on the role of political oligarchies in order to explain the dynamics of post-Reformasi Indonesian politics. Notable scholarships produced by this school of thought include Robison and Hadiz 2004, Hadiz 2010, and Winters 2011. The theoretical insights of the oligarchy school has recently been extended in the analysis of hardline Islamic groups in Indonesia. For these, see Hadiz 2016 and Mudhofir 2017. While political oligarchy scholarship has given meaningful insights on the political economy, material, and power-seeking motivations of hardline Islamic movements, it underplays the role of ideology as a key determinant to the political motivation of these groups, thereby it has troubles explaining why these
} 
misbehaviors and abuses of power of the oligarchs sometimes were reported by the media and different civil society organizations have come out to criticize their abuses, these did little to keep their powers in check, as there are few state institutions that could effectively check their powers and effectively prevent them from committing corruption or other forms of misdeeds while they are holding a public office.

What is more disconcerning for the prospects of civil Islam in Indonesia is the fact that some of these party oligarchs are aligning themselves with hardline Islamist groups in order to further their political ambitions. Former President Susilo Bambang Yudhoyono included a number of Islamist parties, namely PKS, and PPP and PBB as well as developing informal relationships with groups such as HTI. These alliances might have explained his inactions as a number of religious minorities, ranging from Ahmadis, Shiites, and Christians, faced attacks on their houses of workships organized by FPI and other hardline groups. In 2014 former General Prabowo Subianto had won endorsement not just from Islamist parties such as PKS, PBB, and PPP, but also from hardline groups such as FPI. He is widely expected to received endorsement from these groups as he prepared for another presidential run against current President Joko Widodo (Jokowi) in 2019. Prabowo and his family has allegedly financed some of the protests organized by FPI against Ahok in 2016 and 2017 as well.

Exclusivist hardline groups are certainly developing alliances with politicians, civil servants, and security officials who are at sympathetic to their agenda or wants to use the support of these Islamist groups to further their political goals. FPI has cultivated support from high level officials since it was founded in the early 2000s. Retired TNI Chief of Staff Wiranto (now Coordinating Minister for Political, Security, and Legal Affairs) and Police General Nugroho Djajusman were thought to be the organization's chief patron during its early years. Such linkages are maintained with the current leaders of the TNI. General Gatot Nurmantoyo, current TNI Chief, is reportedly having close relations with Habib Rizieq and other senior FPI leaders. At the regional level, FPI has developed relationships with regional Police and TNI commanders as well, which

groups insist on the enactment of local shari'a regulations or other Islamist regulations such as the 2006 Anti Pornography Law even though they are supposedly have managed to secure significant power and material benefits based on their alliances with national and local-level political elites. reportedly has helped it in avoiding legal troubles whenever it launched a strike against a targeted religious minority.

Meanwhile, HTI also had linkages with a number of national and local politicians. For instance, HTI has adopted policy called nusrah ("seeking allies") in order to build alliances with sympathetic government officials both at national and local levels. It has infiltrated the Institute of Local Governance (IPDN), an academy for junior local civil servants to recruit potential cadres within local governments throughout Indonesia. It also hosted "dialogue sessions" with national and local level politicians to propagate its ideas to them. In East Java province, HTI leaders allegedly held several "informal" dialogues with Saifullah Yusuf, the province's Deputy Governor who is currently seeking the nomination to become the province's governor in 2018. He is thought to be instrumental behind the drafting of local regulations that ban both the Ahmadi and Shi'a Islamic sects within the province, a policy that is supported by hardline Islamic groups, including HTI. Lastly, HTI also seems to have recruited several dozen mid-level Indonesian Armed Forces (TNI) officers to become its cadres. It manages to recruit these officers from the da'wa activities it regularly holds at TNI bases over the past decade or so (Interview with a PDIP MP, 7 June 2017). A number of senior retired TNI officers have regularly attended da'wa and other activities sponsored by the organization as well.

To conclude, twenty years of Reformasi has not produced a state that is accountable to its citizens or manages to self-limit potential abuses to its powers from self-serving politicians and their cronies. Legislative, judicial, and other institutions designed to impose a check on potential abuses from executive branches are not effective in performing their jobs effectively In numerous cases, their integrity have been fundamentally compromised due to the cooptation of its functionaries in the patron-client system networks built by the established elites in post-Reformasi Indonesia. Power in Indonesia remains within a small number of elite politicians and their cronies who control the executive branch, whether at national or local levels. Realizing the growing power and influence of hardline Islamist groups, these elites are increasingly forming opportunistic alliances with the latter groups in order to win support from them and tapped in their members as their potential supporters. However, such alliances have proven to be very costly for the longterm prospect of civil Islam in Indonesia, in the form of hundreds of local shari'a regulations as well as 
increasing regulation on public morality at the national level (e.g., the passage of 2006 Anti Pornography Law and the forthcoming passage of an Anti-Alcohol Comsumption Bill in the DPR expected within the next few months). Lastly these alliances have help contributed to the growing persecution and violence against Muslim minorities and other religious minorities, which were conducted by hardline Islamists with much impunity as no state apparatus were willing to stop them due to the networks these groups have had with senior politicians and security officials. With these, the prospect of a civil Islamic principles and discourses prevailing in a democratic, post-Reformasi Indonesia, remains a distant dream.

\section{Concluding Remarks}

Robert Hefner's Civil Islam, released immediately after Indonesia successfully completed its first post-Reformasi election in 1999, is written with an idealist vision on how Indonesia, one of the few Muslim-majority countries which successfully democratic transition, could become a civil pluralist state, driven by moderate Islamic groups and activists which had successfully shepherd the country's transition to democracy. It made a sweeping universalistic assumption based on how religious civil society associations in the United States have contributed to democratic consolidation within the country as well, and it argued that Indonesia's transition to democracy was a successful case study that Muslims also share the civil, pluralist mindset, that contributes to the long-term sustainability of democracy within a given society. The three preconditions of successful democratization - the presence of strong civil associations, a pluralist public culture, and a self-limiting state, were written with the hope that one day Muslim-majority countries like Indonesia can become sustained democratic states, which practices civil Islamic principles within their politics and society.

However, while there are numerous moderate Muslims which shares the civil, pluralist public culture advocated by Hefner, the hope that Indonesia would become a successful, consolidated democracy remains elusive two decades after Reformasi. While civic associations grew exponentially in post Reformasi Indonesia, it does not consist of just moderate Islamic groups, but also hardline Islamist ones. Gradually, the latter manages to overperform the former in gaining new recruits at public high schools, university campuses, and both traditional and online $d a$ 'wa activities, thanks to their ability to craft simplistic answers based on the literal interpretation of the Qur'an to the theological questions posted by young, middle class Muslims, their effectiveness in adapting to new outlets to express their ideas (e.g., television and social media) and their ability to develop effective networks with national and local politicians and the conservative clerics and activists within the NU and Muhammadiyah. At the same time, moderate activists seem to be constrained in their ability to challenge the theological claims of the hardline groups, due to personal rivalries among themselves, and their preoccupation to participate in political affairs rather than da'wa affairs in post-Reformasi Indonesia.

As a result of this, Indonesia's public culture is increasingly filled with hardline ideologies advocated by conservative Islamist groups, characterized with their intolerance against Muslim minorities, nonMuslims, or any other groups who are trying to challenge the ideological hegemony of these hardline groups. As a result, thousands of intolerance incidents occurred in Indonesia against various religious minorities over the past two decades, while the state does virtually nothing to provide protection to these persecuted minorities. At the same time, rather than a self-limiting state that is kept checked by both watchdog institutions and civil society groups, the Indonesian state remains captured to the interests of a small group of elites who dominated the country's political and socio-economic affairs. These elites, whether at national or local level, often develop alliances with hardline Islamists in order to retain their political power. Such an alliance does not just benefit the elites, but also helped hardline groups to make additional gains in their goal to further push the Indonesian state and society towards a more Islamic direction. The enactment of hundreds of local shari'a regulation in post-Reformasi Indonesia is just one example of the consequences of the alliances between hardline Islamist and the political elites, often made by instrumental reasons but comes with negative repercussions for the groups affected by these regulations - women, religious minorities, as well as others.

It is clear that two decades after Reformasi, the dream of Civil Islam to be instituted within the Indonesian state and society remains an elusive one, as moderate Islamic groups continue to lose ground against hardline Islamists and political elites keep appeasing the latter by instituting Islamist-friendly laws and regulations in order to secure political 
support from these groups. As long as the moderate groups do not try to find ways to promote their civil pluralist Islam in a more effective manner and fully engage the hardline groups in the free marketplace of ideas created after Indonesia's democratic transition, the latter will continue to make gains and dominate the public discourses in post-Reformasi Indonesia. The hardliners will not stop until they eventually managed to establish a NKRI Bersyariah or a similar state-society arrangement where the formalization of strict Islamic principles guide the Indonesian state. When that happens, Indonesia will become a totally different state, not a Civil Islamic one that was hoped by Hefner and other proponents of his thesis.

\section{REFERENCES}

Ambardi, K. (2008). The Making of the Indonesian Party System: A Cartelized Party and Its Origin. Ph.D. Dissertation, Department of Political Science, The Ohio State University.

Arifianto, A. (2012). Faith, Moral Authority, and Politics: The Making of Progressive

Islam in Indonesia. Ph.D. Dissertation, School of Politics and Global Studies, Arizona State University.

Arifianto, A. (2017). "Islam Nusantara and Its Critics: The Rise of NU's Young Clerics,”

RSIS Commentary No. 018/2017, 23 January. Online at: https://www.rsis.edu.sg/rsispublication/rsis/co17018-politics-plurality-andinter-group-relations-in-indonesia-islamnusantara-its-critics-the-rise-of-nus-youngclerics/\#.WZrR6dFLfIU, accessed 21 August 2017.

Assyaukanie, L. (2009). Islam and the Secular State in Indonesia. Singapore: Institute of Southeast Asian Studies Publishing.

Azra, A. (2006). Indonesia, Islam, and Democracy: Dynamics in a Global Context. Jakarta, Indonesia: Solstice Publishing.

Azra, A., K.V. Dijk, and N.J.G Kaptein (eds) (2010). Varieties of Religious Authority: Changes and Challenges in $20^{\text {th }}$ Century Indonesian Islam. Singapore: Institute of Southeast Asian Studies Publishing.

Budiwanti, E. (2009). "Pluralism Collapses: A Study of the Jamaah Ahmadiyah Indonesia and Its Persecution,” Asia Research Institute, Working Paper No. 117 (May), https://ari.nus.edu.sg/publication/detail/1370, (accessed 22 August 2017).

Buehler, M. (2012). “Revisiting the Inclusion-Moderation Thesis in the Context of
Decentralized Institutions: The Behavior of Indonesia's Prosperous Justice Party in National and Local Politics,” Party Politics, Vol. 19, No. 2 (April), pp. 210-229.

Burhani, A.N. (2014), “Treating Minorities with Fatwas: A Study of the Ahmadyya Community in Indonesia," Contemporary Islam, Vol. 8, No. 2, pp. 285-301.

Bush, R. (2009). Nahdlatul Ulama and the Struggle for Power within Islam and Politics in Indonesia. Singapore: Institute of Southeast Asian Studies Publishing.

Butt, S. (2011). “Anti-Corruption Reform in Indonesia: An Obituary?” Bulletin of Indonesian Economic Studies, Vol. 47, No. 3, pp. 381-394.

Fogg, K. (2012). The Fate of Muslim Nationalism in Independent Indonesia. Ph.D.

University.

Dissertation, Department of History, Yale

Formichi, C. (2014). "Violence, Sectarianism, and the Politics of Religion: Articulations of

Anti Shi'a Discourses in Indonesia,” Indonesia, Vol. 98, pp. 1-27.

Geertz, C. (1960). The Religion of Java. New York: The Free Press. First Edition.

Hadiz, V. (2010). Localizing Power in Post-Authoritarian Indonesia: A Southeast Asia

Perspective. Stanford, CA: Stanford University

Press.

Hadiz, V. (2016). Islamic Populism in Indonesia and the Middle East. New York: Cambridge University Press.

Hamayotsu, K. (2011). "Beyond Faith and Identity: Mobilizing Islamic Youth in a Democratic Indonesia, The Pacific Review, Vol. 24, No. 2, pp. 225-247

Hamayotsu, K. (2011). "The Political Rise of the Prosperous Justice Party In PostAuthoritarian Indonesia,” Asian Survey, Vol. 51, No. 5, pp. 971-992

Hamayotsu, K. (2011). “The End of Political Islam? A Comparative Analysis of Religious Parties in the Muslim Democracy Indonesia," Journal of Current Southeast Asian Affairs, Vol. 30, No. 3 (2011), pp. 133-159.

Hasan, N. (2017). Public Islam in Indonesia: Piety, Politics, and Identity. Amsterdam, the Netherlands: Amsterdam University Press. 
Hefner, R.W. (2000). Civil Islam: Muslims and Democratization in Indonesia. Princeton,

NJ: Princeton University Press.

Hoesterey, J.B. (2016). Rebranding Islam: Piety, Prosperity, and a Self-Help Guru.

Stanford, CA: Stanford University Press.

Hudson, W. and A. Azra (eds.) (2017). Islam Beyond Conflict: Indonesian Islam and Western Political Theory. London: Routledge.

Human Rights Watch. "In Religion's Name: Abuses Against Religious Minorities in Indonesia,”

HRW Research Report (February 28, 2013). Available online at: https://www.hrw.org/report/2013/02/28/religionsname/abuses-against-religious-minoritiesindonesia (accessed 1 July 2017).

Huntington, S. (1996). The Clash of Civilizations and the Remaking of the World Order.

New York: Simon \& Schuster.

Institute for Policy Analysis \& Conflict. “The Anti Shi’a Movement in Indonesia,” IPAC Report
No. $27 \quad$ (27 $\quad$ April 2016) http://www.understandingconflict.org/en/conflict/ read/50/THE-ANTI-SHIA-MOVEMENT-ININDONESIA (accessed 22 August 2017).

Jung, E. (2009). Taking Care of the Faithful: Islamic Organizations and Partisan

Engagement in Indonesia, Ph.D. Dissertation, Department of Political Science, University of Wisconsin-Madison.

Kadir, S.A. (1999). Traditional Islamic Society and the State in Indonesia: The

Nahdlatul Ulama, Political Accommodation, and the Preservation of Autonomy. Ph.D. Dissertation, Department of Political Science, University of Wisconsin - Madison.

Kailani, N. (2015). Aspiring to Prosperity: The Economic Theology of Urban Muslims in

Contemporary Indonesia. Ph.D. Dissertation, School of Humanities and Social Sciences, University of New South Wales Canberra, Australia.

Laffan, M. (2003). Islamic Nationhood and Colonial Indonesia: The Umma below he Winds. London: RoutledgeCurzon.

Lewis, B. (1993). Islam and the West. New York: Oxford University Press.

Lewis, B. (2003). What Went Wrong? The Clash between Islam and Modernity in the

Middle East. New York: Perennial.
Maarif Institute (2016), A Survey of West Java Public High School Students Attitudes towards Shari'a Law, Unpublished report commissioned for the Indonesian Ministry of Religious Affairs.

McBeth, J. (2017). “Jokowi and the General," The Strategic, Australian Strategic Policy Institute $\quad(13 \quad$ January),
https://www.aspistrategist.org.au/jokowi-and-the-
general/(accessed 24 August 2017).

Menchik, J. (2016). Islam and Democracy in Indonesia: Tolerance without Liberalism. New York: Cambridge University Press.

Mietzner, M. (2010). "Political Conflict Resolution and Democracy in Indonesia: The Role of the Constitutional Court, Journal of East Asian Studies, Vol. 10, pp. 397-424.

Mietzner, M. (2012). “Indonesia’s Democratic Stagnation: Anti-Reformist Elites and Resilient Civil Society,” Democratization, Vol. 19, No. 2, pp. 209-229.

Mudhofir, A.M. (2017). "Islamic Militias and Capitalist Development in PostAuthoritarian Indonesia," Journal of Contemporary Asia, Vol, 47, No. 4, pp. 495-514.

Muhtadi, B. (2009). "The Quest for Hizbut Tahrir in Indonesia," Asian Journal of Social Science, Vol. 37, No. 4, pp. 623-645.

Muhtadi, B. (2015). “Jokowi’s First Year: A Weak President Caught between Reform and Oligarchic Politics,” Bulletin of Indonesian Economic Studies, Vol. 51, No. 3, pp. 349-368.

Munabari, F. (2017). "Reconciling Shari'a with "Negara Kesatuan Republik Indonesia”: The Ideology and Framing Strategies of the Indonesian Forum of Islamic Society (FUI)," International Area Studies Review, online edition, pp. 1-22.

Njoto-Feillard, G. (2015). "Hizbut Tahrir Indonesia in 2014: The Political Economy of

Discontent," ISEAS Trends in Southeast Asia Series, Working Paper \#2015-19 (Singapore: Institute of Southeast Asian Studies), https://www.iseas.edu.sg/images/pdf/TRS19 15. pdf, accessed 21 April 2017.

Osman, M.N.M. (2010). "Reviving the Caliphate in the Nusantara: Hizbut Tahrir Indonesia’s

Mobilization Strategy and Its Impact in Indonesia," Terrorism and Political Violence, Vol. 22, No. 4, pp. 601-622.

Pisani, E. and M. Buehler (2017). "Why do Indonesian Politicians Promote Shari'a 
Laws? An Analytic Framework for Muslimmajority Democracies,” Third World Quarterly, Vol. 38, No. 3, pp. 734-752.

Platzdasch, B. (2009). Islamism in Indonesia: Politics in the Emerging Democracy. Publishing.

Singapore: Institute of Southeast Asian Studies

Platzdasch, B. (2013). "Religious Freedom in Contemporary Indonesia: The Case of the

Ahmadiyah," in Hui Yew-Foong (ed.). Encountering Islam: The Politics of Religious Identities in Southeast Asia. Singapore: Institute of Southeast Asian Studies Publishing, pp. 218246.

Rinaldo, R. (2013). Mobilizing Piety: Islam and Feminism in Indonesia. New York: Oxford

University Press.

Robison, R. and V. Hadiz (2004). Reorganising Power in Indonesia: The Politics of

Routledge.

Oligarchy in an Age of Markets. London:

Sandal, N. (2017). Religious Leaders and Conflict Transformation: Northern Ireland and

Beyond. New York: Cambridge University Press.

Sherlock, S. (2012). "Made by Committee and Consensus:

Parties and Policy in the Indonesian Parliament," Southeast Asia Research, Vol. 20, No. 4, pp. 551-568.

Slater, D. (2004). “Indonesia’s Accountabilty Trap: Party Cartels and Presidential Power after

Democratic Transition,” Indonesia, Vol. 78, pp.

61-92.

Tanuwidjaja, S. (2012). "PKS in Post-Reformasi Indonesia: Catching the Catch-All and

Moderation Wave," Southeast Asia Research, Vol. 20, No. 4, pp. 533-549

Tibi, B. (2002). The Challenge of Fundamentalism: Political Islam and the New World

Disorder. Berkeley, CA: University of California

Press.

Tibi, B (2012). Islamism and Islam. New Haven, CT: Yale University Press.

Tomsa, D. (2012). “Moderating Islam in Indonesia: Tracing Patterns of Party Change in the

Prosperous Justice Party," Political Research Quarterly, Vol. 65, No. 3, pp. 486-498

Ward, K. (2009). "Non-violent Extremists? Hizbut Tahrir Indonesia," Australian Journal of

International Affairs, Vol. 63, No. 2, pp. 149-
Winters, J. (2011). Oligarchy. New York: Cambridge University Press.

Ziegenhain, P. (2008). The Indonesian Parliament and Democratization. Singapore: Institute of Southeast Asian Studies Publishing.

164. 